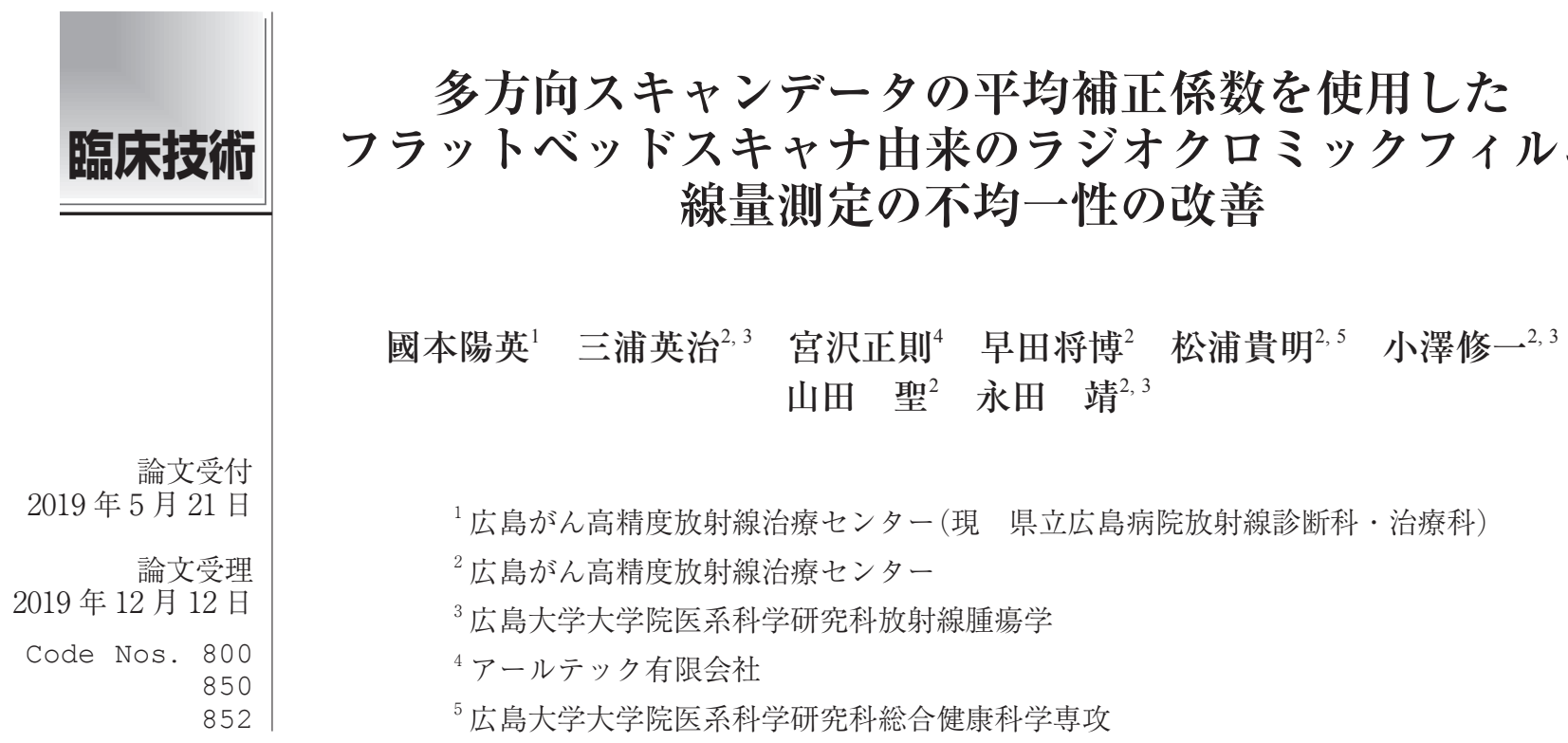

緒 言

therapy (IMRT) や volumetric modulated arc therapy

高精度放射線治療である intensity modulated radio-

(VMAT)は，標的臓器への線量集中性を高めつつリ

\title{
Improvement of Nonuniformity on Flatbed Scanner for Radiochromic Film Dosimetry Using Average Correction Factor with Multi-direction Scan Data
}

Haruhide Kunimoto, ${ }^{*}$ Hideharu Miura, ${ }^{2,3}$ Masanori Miyazawa, ${ }^{4}$ Masahiro Hayata, ${ }^{2}$ Takaaki Matsuura, ${ }^{2,5}$ Shuichi Ozawa, ${ }^{2,3}$ Kiyoshi Yamada, ${ }^{2}$ and Yasushi Nagata ${ }^{2,3}$

${ }^{1}$ Hiroshima High-Precision Radiotherapy Cancer Center(Current address: Department of Diagnostic Radiology /Radiation Oncology, Hiroshima Prefectural Hospital)

${ }^{2}$ Hiroshima High-Precision Radiotherapy Cancer Center

${ }^{3}$ Department of Radiation Oncology, Graduate School of Biomedical \& Health Sciences, Hiroshima University

${ }^{4}$ R-TECH.INC

${ }^{5}$ Division of Integrated Health Sciences, Graduate School of Biomedical \& Health Sciences, Hiroshima University

Received May 21, 2019; Revision accepted December 12, 2019

Code Nos. $800,850,852$

\section{Summary}

In order to correct the lateral effect caused by the light source of the flatbed scanner in the Gafchromic film EBT3, the usefulness of the correction method using the average value of the correction coefficient considering the scan directions were evaluated. EBT3 was scanned from four directions to measure the optical density (OD) of the red, blue, and, red/blue components and the correction coefficient were calculated. For the correction coefficients, average values were calculated for the purpose of use, when the scan directions could not be aligned (average lateral effect correction). Correction accuracy was verified with the pass rate of gamma analysis ( $3 \mathrm{~mm} / 3 \%$, threshold $30 \%$ ) of the dose distribution using the EBT3 film irradiated with the step pattern. OD of the red, blue, and, red/blue components in the scanning vertical direction tended to be higher in the center than in the peripheral portion. The pass rate of the step pattern was the red component's before correction, from 26.9 to $45.1 \%$ (before correction), from 84.1 to $96.7 \%$ (after correction), the red/blue component, from 37.6 to $48.4 \%$ (before correction) and from 84.4 to $96.7 \%$ (after correction). When using the correction coefficient using the average value, the pass rate was $89.8 \%$ for the red component and $94.7 \%$ for the red/blue component. The lateral effect correction improves the accuracy of the dose distribution verification, and the correction coefficient using the average value is useful when the scanning direction is different from that at the time of obtaining the dose concentration curve.

Key words: lateral effect, Gafchromic film, EBT3, average lateral effect correction, gamma analysis

*Corresponding author 
スク臓器の線量を下げることができる照射方法として 使用されている。これらの照射方法は, multileaf collimator (MLC)の形状変化だけでなくガントリ回転速 度や線量率が変化するため, 3 dimensional conformal radiation therapy (3D-CRT) などの従来の照射方法と 比較して線量分布は複雑であり, 局所に抢ける線量勾 配も急峻である。そそのため，それらの装置精度が投与 線量へ影響する可能性があるため, 治療開始前に患者 毎の線量検証を実施する必要がある，線量検証は，電 離箱を用いる評価点線量検証とフィルムを用いる線量 分布検証が推奨されている ${ }^{1)}$. フィルムは高い空間分 解能を有し，照射範囲の形状が把握できるため広く使 用されている。また，フィルムは，現像を必要とする ラジオグラフィックフィルム (radiographic film: RGF) と現像を必要としないラジオクロミックフィルム (radiochromic film: RCF)に分類できる. RGF は感光物 質に人体組成と異なる銀粒子を用いているため，放射 線治療領域では人体組成に等価な放射線特性を有する RCF が用いられている，近年は，フィルムレス化に より現像機を所有していない施設も多いことから, $\mathrm{RCF}$ の需要は高い. RCF は, 放射線に反応して着色 するモノマの感応層と癒着層がクリアポリエステルな どでラミネートされた構造である，主に患者個別の品 質保証 (quality assurance: QA)で使用されている RCF として, EBT3 や EBT-XD (Ashland 社)が挙げられ る. EBT3 は通常治療で使用する線量における IMRT の線量分布検証，EBT-XD は定位放射線治療のように 大線量で小照射野の線量分布検証に用いられる ${ }^{2)}$.

RCF は，フラットベッドスキャナを使用してス キャンすることが一般的である. RCF はフラット ベッドスキャナでスキャンする際，スキャナ光源の走 査方向に対して垂直方向で顕著な不均一性 (lateral effect）を示す特徴がある ${ }^{3,4)}$. Lateral effectは, フィル ム自体の粒子ムラや感光物質の塗布ムラなど素材や構 造とフラットベッドスキャナの組み合わせに起因する ものであり, 感光物質の粒子ムラや塗布ムラはロット によって影響は異なる， RCF の感光物質の粒子ムラ や塗布ムラの影響を低減する方法は, 平坦度情報であ る青色成分を利用した red/blue correction 法 $^{5 \sim 7)}$ や triple-channel 法8.9), 校正用フィルムを利用した background correction 法がある ${ }^{10)}$. Lateral effect は, 補正によって測定精度の改善が期待できるため, 赤色 成分と赤色/青色成分に打いて補正法の有用性が報告 されている ${ }^{11)}$. EBT3 の感光物質は放射線感受性モノ マが棒状構造のため, スキャン時に向きおよび表裏の スキャン方向依存性がある。方向依存性は, RCFの
線量測定の際に生じる不確かさの一つとされており, 線量分布検証に影響するためフィルムスキャン方向と lateral effectの関係性について把握することは非常に 重要である ${ }^{12 \sim 14)}$ ，通常の線量分布検証は，同一ロット においては線量-濃度曲線 (特性曲線) 取得時とフィル ムスキャン方向を一致させることで方向依存性の影響 を低減しているが，頭頸部や骨盤部のように比較的広 範囲な治療領域の線量分布検証時は必ずしもフィルム スキャン方向を揃えることはできない. Lateral effect は, EBT-XD では定位放射線治療のような大線量, 小 照射野で使用するため問題にならないが，EBT3では 大照射野を対象とする場合があり無視できない，過去 に, フィルムの粒状性が lateral effect に及ぼす影響に ついてスキャン方向を $90^{\circ}$ 回転させて評価した報告は あるが，フィルムのスキャン方向および表裏を考慮し て lateral effectを評価した報告はされていない4). 更 に, lateral effect 補正をする際に, lateral effect 補正 係数として複数方向の平均值を使用した報告もされて いない.

本研究では, 線量分布検証のために使用する EBT3 に拈いて，フラットベッドスキャナによるスキャン時 に発生するスキャナ由来の不均一性を補正する方法を 検討した. Lateral effectはスキャン方向によって フィルム固有のムラが影響し optical density (OD)が 変化することを考慮し, EBT3 は 4 方向からスキャン し, 赤色成分, 青色成分, 赤色/青色成分の OD と lateral effect 補正係数を算出した. Lateral effect 補正 係数は, 線量分布検証で lateral effect 補正の正確性を 評価し，広い照射野でスキャン方向を一致させること ができない場合を考慮して OD の平均值から算出し た lateral effect 補正係数 (average lateral effect 補正 係数)の有用性も評価した。

\section{1. 方 法}

\section{1-1 使用機器とスキャン条件}

RCF は, radiochromic EBT3 (Lot\#: 06051404, Veritas 社)を使用した。EBT3は，活性層が保護層の ポリエステルで対称的に挟まれている。この保護層の 表面に凹凸を付加することによってニュートンリング のような不均一の障害院影は除去できる. 直線加速器 は TrueBeam STx (Varian Medical Systems 社), 治療 計画装置 (treatment planning system: TPS)は Eclipse Ver.13.5 (Varian Medical Systems 社), エネルギーは 6MV-X 線, 計算アルゴリズムは Acuros XB を使用し た. TPSの線量計算グリッドサイズは, $2.0 \mathrm{~mm}$ に設 定した。フラットベッドスキャナは, ES-10000G 


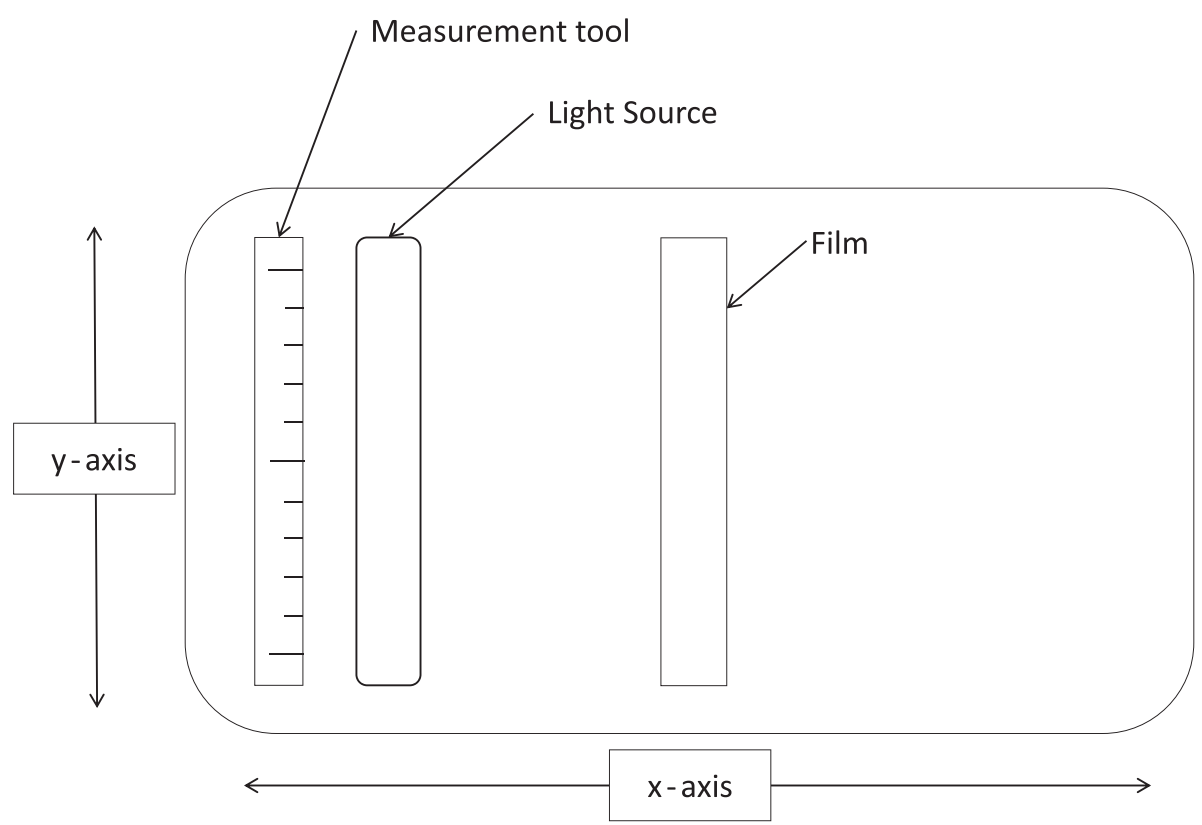

Fig. 1 Geometric layout of Epson 10000 XL scanner.

The scanning movement direction of the light source was the $\mathrm{x}$-axis, and direction parallel to the light source was the y-axis. The long axis of the EBT3 was parallel to the $y$-axis, and the EBT3 was arranged by the measure tool and can be measured at the same position every scan.

(EPSON 社)を使用した。フィルムの幾何学的配置を Fig. 1 に示す. 本研究では, スキャナ光源の走査方向 を $\mathrm{x}$ 軸，走査垂直方向を $\mathrm{y}$ 軸とした。フィルムは，2x $25 \mathrm{~cm}^{2}$ の大きさに切断し, $\mathrm{y}$ 軸に対してフィルムの長 軸が対応するように配置した。 スキャンは, 放射線照 射後のフィルム濃度安定を考慮して照射 24 時間後と した。スキャン条件は, 分解能を 75 dot per inch (dpi)，48 bit 三原色成分ですべて 3 回スキャンの平均 值を測定結果として TIFF 形式で保存した。フィルム の配置は, 位置誤差を最小限にするためスキャナ $\mathrm{y}$ 軸 に定規を設置して毎回同一位置でスキャンした。ス キャンした結果の画素值 (pixel value: PV) は, 式(1)を 用いて ODに変換した。

$\mathrm{OD}=-\log _{10}(\mathrm{PV} / 65535)$

\section{1-2 EBT3 における特性曲線と lateral effect 補正係数}

幾何学的配置は, EBT3 を水等価ファントム (京都 科学社)の深さ $10 \mathrm{~cm}$ 地点に設置して source-surface distance を $90 \mathrm{~cm}$ とした。 また, 後方散乱を考慮して $\mathrm{EBT} 3$ の下に $10 \mathrm{~cm}$ 厚の水等価ファントムを設置し た。照射野サイズは，切断したフィルムを十分に含む ことができる $5 \times 30 \mathrm{~cm}^{2}$, 処方線量は $0,10,25,50,100$, 150, 200, 250,300, 400 cGy に設定した. スキャンは, lateral effect に対するフィルム固有のムラの影響を考
慮して 4 方向で行った。 スキャン方向は, フィルムの 右上に印があるときを Right-Up-Front(RUF)，右下を Right-Down-Back(RDB), 左下を Left-Down-Front $(\mathrm{LDF})$ ，左上を Left-Up-Back (LUB)とした。スキャ ン範囲は、 $\mathrm{x}$ 軸 $1 \mathrm{~cm}, \mathrm{y}$ 軸 $18 \mathrm{~cm}$ とした。フィルム不 均一性補正は, フィルム解析ソフトウエア 2D-Flat プ ログラム (R-TECH 社)を使用した。 2D-Flat プログラ ムの手順は，スキャン方向別に赤色成分，青色成分， 赤色/青色成分で $\mathrm{y}$ 軸位置に対応させて特性曲線が作 成される。赤色成分, 青色成分の OD は式(2), 式(3) で算出し，赤色/青色成分に関しては OD $D_{R E D}$ から $\mathrm{OD}_{\mathrm{BLUE}}$ を除することにより算出される. Lateral effect 補正係数は，y 軸位置に対応した特性曲線を算出 し，y軸位置における処方線量とOD との $\mathrm{y}$ 軸中央に 対する比となる. Average lateral effect 補正係数の算 出方法を Fig. 2 に示す。設定した線量で照射した フィルムは, 2D-Flat プログラムで各スキャン方向の スキャン位置と線量に対応した PVに変換される. Figure 2 に示されるように各スキャン方向の PVは, OD に変換後に平均值を算出し, その平均値を用いて average lateral effect 補正係数を算出される。設定し た処方線量間の lateral effect 補正係数は, 離散的であ るため内挿してデー夕補間される。 
RUF , RDB , LDF and LUB

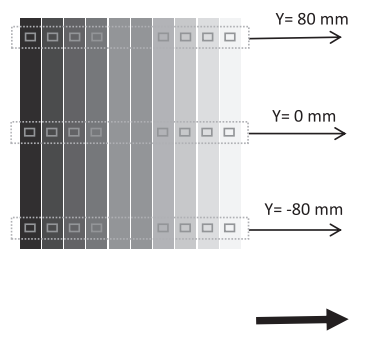

Scan
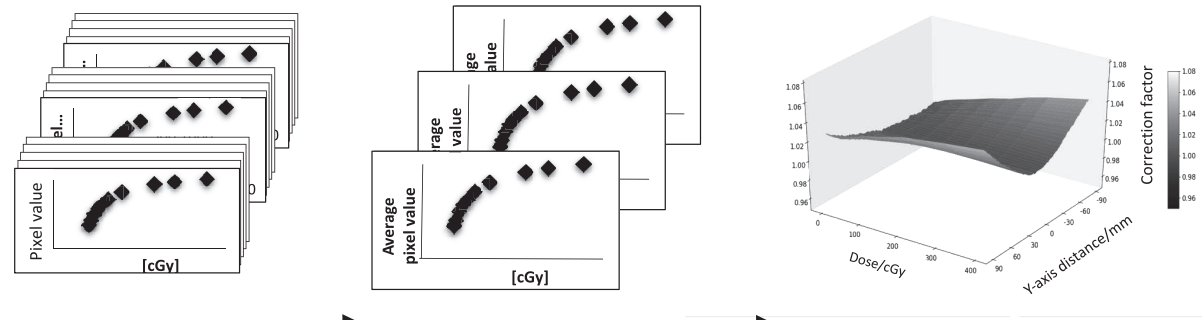

Calculate factor

Fig. 2 Average lateral effect correction factor calculation method.
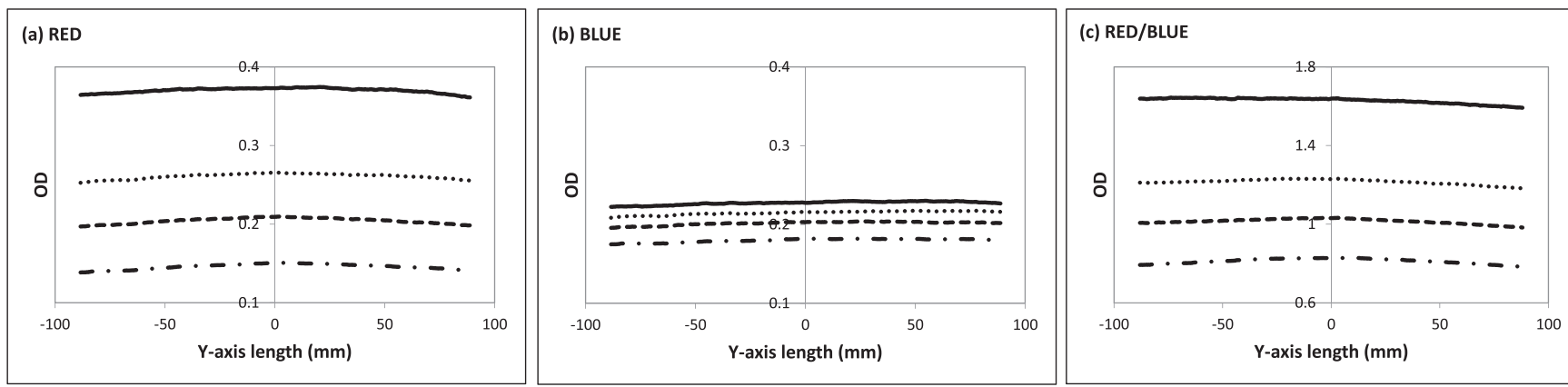

0 cGy

100 cGy

200 cGy - - 400 cGy

Fig. 3 Optical density profile for (a) red, (b) blue and (c) red/blue components of non-irradiated and irradiated (100, 200 and 400 cGy) EBT3 film pieces scanned along the y-axis.

$\mathrm{OD}_{\mathrm{RED}}=-\log _{10}\left(\mathrm{PV}_{\mathrm{RED}} / 65535\right)$

$\mathrm{OD}_{\mathrm{BLUE}}=-\log _{10}\left(\mathrm{PV}_{\mathrm{BLUE}} / 65535\right)$

\section{1-3 Lateral effect 補正係数の正確度検証}

Lateral effect 補正係数による補正が線量分布検証 に及ぼす影響について調べた。 Lateral effect 補正係 数の正確度検証は, ステップパターンと頭頸部 IMRT プランを照射したフィルムを用いた。幾何学的条件は 1-2 と同様とし, 照射したフィルムはスキャナに RUF 方向で配置してスキャンした。スキャン結果は，2DFlat プログラムで赤色成分と赤色/青色成分の補正有 無のデータを取得し, TPSで算出した線量分布と比較 してガンマ解析のパス率で評価した。解析条件は, $3 \%$ dose difference(DD) $/ 3 \mathrm{~mm}$ distance to agreement (DTA), threshold 30\%に設定した。

\section{1-3-1 ステップパターン}

ステップパターンは, $20 \times 25 \mathrm{~cm}^{2}$ のフィルムに 2.5 $\mathrm{cm}$ 間隔の 5 段ステップで処方線量 100, 170, 250, 320,
380 cGy を照射した

\section{1-3-2＼cjkstart頭頸部 IMRT プランのデータ取得}

頭頸部 IMRT プランは, lateral effect の影響が大き いと考えられる広い照射野を必要とする頭頸部領域と した。頭頸部IMRT プランは, ATOM ファントム (CIRS 社) に計画標的体積 (planning target volume: PTV)を作成後, 水等価ファントムにマッピングして $20 \times 25 \mathrm{~cm}^{2}$ のフィルムに照射した，処方線量は，PTV に対して $200 \mathrm{cGy}$ (D95\%処方)とした。

\section{2. 結 果}

\section{2-1 スキャン方向による OD の変化}

Figure 3 に赤色成分, 青色成分, 赤色/青色成分の OD を示す. Figure 3 に示すようにODのプロファイ ルは, 赤色成分, 青色成分, 赤色/青色成分のすべてに おいて中央より周辺部で OD が低い傾向であり, 線量 が高いほどその傾向は強く, $400 \mathrm{cGy}$ のきに差は最 大となり，それぞれ 7.4, 3.5, 5.6\%であった. Figure 4 に処方線量 200, 400 cGy のフィルムのスキャン方向を 
変化させたときの OD を示す. Figure 4 に示すよう に, $\mathrm{y}$ 軸中央からの距離が同じであっても OD の変化 は非対称であった。赤色成分, 青色成分, 赤色/青色成 分における $\mathrm{y}$ 軸中央からの距離に応じたスキャン方 向による OD の変化は, 傾向は同じであったが, 変化 率はそれぞれ異なった。

\section{2-2 Lateral effect 補正係数}

Lateral effect 補正係数は, 患者 QA で使用される機 会が多い赤色成分と赤色/青色成分とした，赤色成分 と赤色/青色成分の lateral effect 補正係数は, 2-1 の OD から 2D-Flat プログラムを使用して算出される.

Figure 5 に赤色成分および赤色/青色成分の lateral effect 補正係数を示す. Lateral effect 補正係数は, y 軸 中央からの距離が離れるとともに差は顕著になり非対 称となった．赤色成分および赤色/青色成分において も同様の傾向であった. Lateral effect 補正係数は, 赤 色成分と赤色/青色成分において中央より周辺部で高 い傾向であった. Lateral effect 補正係数の線量依存 性は, $400 \mathrm{cGy}$ のときに最大であり, 赤色成分は 8.7\%，赤色/青色成分は 6.0\%であった.

\section{2-3 Lateral effect 補正係数の正確度検証}

Lateral effect 補正の有用性は, 補正前後の線量分布 を比較することで検証した. Lateral effect 補正は，す べてのスキャン方向において補正前で中央より周辺部 で線量差が大きく, 補正後で周辺部の線量差は低減し た. ガンマ解析評価では, 補正前は周辺部においてガ ンマ值が 1 を超える領域が多く, 補正後はガンマ值が 1 を超える領域は減少し, パス率は改善した。

\section{2-3-1 ステップパターン}

Lateral effect 補正前後で比較した線量プロファイ ルと線量分布を Fig. 6 に示す. 線量プロファイルに おいて補正前後の線量差は, y 軸中央から $100 \mathrm{~mm}$ 離 れた位置で最大となった。測定位置が $\mathrm{y}$ 軸中央 $0 \mathrm{~mm}$ と $100 \mathrm{~mm}$ 離れた位置に扔ける線量差を Table 1 に示 す. $100 \mathrm{~mm}$ 離れた位置での補正前後における線量差 の平均士標準偏差は, 補正前が赤色成分で $16.3 \pm 2.5 \%$, 赤色/青色成分で $18.8 \pm 3.3 \%$ であり, 補正後が赤色成分 で $1.7 \pm 1.2 \%$ ，赤色/青色成分で $0.6 \pm 1.4 \%$ であた．各 スキャン方向における補正前後のパス率を Table 2 に 示す，パス率は，赤色成分では補正前が 26.9-45.1\%, 補正後が 84.1-96.7\%，赤色/青色成分では補正前が 37.6-48.4\%, 補正後が 84.4-96.7\%となった。 パス率 は, LDF が最も低い結果となり, 赤色成分で $84.1 \%$, 赤色/青色成分で 84.4\%であった. Average lateral ef- fect 補正係数を使用した場合では，パス率が赤色成分 で $89.8 \%$ ，赤色/青色成分で $94.7 \%$ となり，赤色/青色 成分が $4.9 \%$ 高い值を示した，特性曲線取得時と同一 方向であるRUF 方向と average lateral effect 補正係 数を使用して補正したガンマ解析のパス率は, RUF 方向が赤色成分で $3.7 \%$ ，赤色/青色成分で $2.0 \%$ 高 かった，特性曲線取得時と線量分布検証時のフィルム スキャン方向を一致させることができない場合, average lateral effect 補正係数を使用して補正したガ ンマ解析のパス率は, LDF に対して赤色成分で $5.7 \%$ ，赤色/青色成分で $10.3 \%$ 高かった。

\section{2-3-2 頭頸部 IMRT プラン}

Lateral effect 補正前後で比較した線量プロファイ ルと線量分布を Fig. 7 に示す. 線量プロファイルに 扔いて補正前後の線量差は, y 軸中央から $80 \mathrm{~mm}$ 離 れた位置で最大となった。測定位置が $\mathrm{y}$ 軸中央 $0 \mathrm{~mm}$ と $80 \mathrm{~mm}$ 離れた位置に扮ける線量差を Table 3 に示 す. $80 \mathrm{~mm}$ 地点での補正前後に打ける線量差の平均土 標準偏差は, 補正前が赤色成分で $16.2 \pm 1.0 \%$, 赤色/青 色成分で $21.2 \pm 0.7 \%$ であり, 補正後が赤色成分で $1.8 \pm$ $0.6 \%$ ，赤色/青色成分で $2.1 \pm 0.8 \%$ であった，各スキャ ン方向に扮ける補正前後のパス率を Table 4 に示す. パス率は赤色成分で補正前が58.9-61.2\%，補正後が 91.1-98.7\%，赤色/青色成分で補正前が59.3-63.3\%， 補正後が 90.8-98.6\%となった。 パス率は, LDFが最 も低い結果となり, 赤色成分で $91.1 \%$, 赤色/青色成分 で 90.8\%であった. Average lateral effect 補正係数を 使用した場合では, パス率が赤色成分で $96.1 \%$, 赤色/ 青色成分で $98.5 \%$ となり，赤色/青色成分が $2.4 \%$ 高い 值を示した，特性曲線取得時と同一方向である RUF 方向と average lateral effect 補正係数を使用して補正 したガンマ解析のパス率は, RUF 方向が赤色成分で $2.6 \%$, 赤色/青色成分で $0.1 \%$ 高かった。特性曲線取得 時と線量分布検証時のフィルムスキャン方向を一致さ せることができない場合, average lateral effect 補正 係数を使用して補正したガンマ解析のパス率は, LDF に対して赤色成分で $5.0 \%$ ，赤色/青色成分で $7.7 \%$ 高 かった。

\section{3. 考察}

本研究では, EBT3におけるフラットベッドスキャ ナ由来の不均一性の補正方法について検討した。 Lateral effect は, 過去の報告と同様に $400 \mathrm{cGy}$ までの 線量領域において $\mathrm{y}$ 軸中央からの距離とともに出現 し, 線量が高いほど影響は大きかった ${ }^{3,4)}$. 赤色成分, 青色成分に扮ける周辺部の線量差は, 赤色成分で大き 

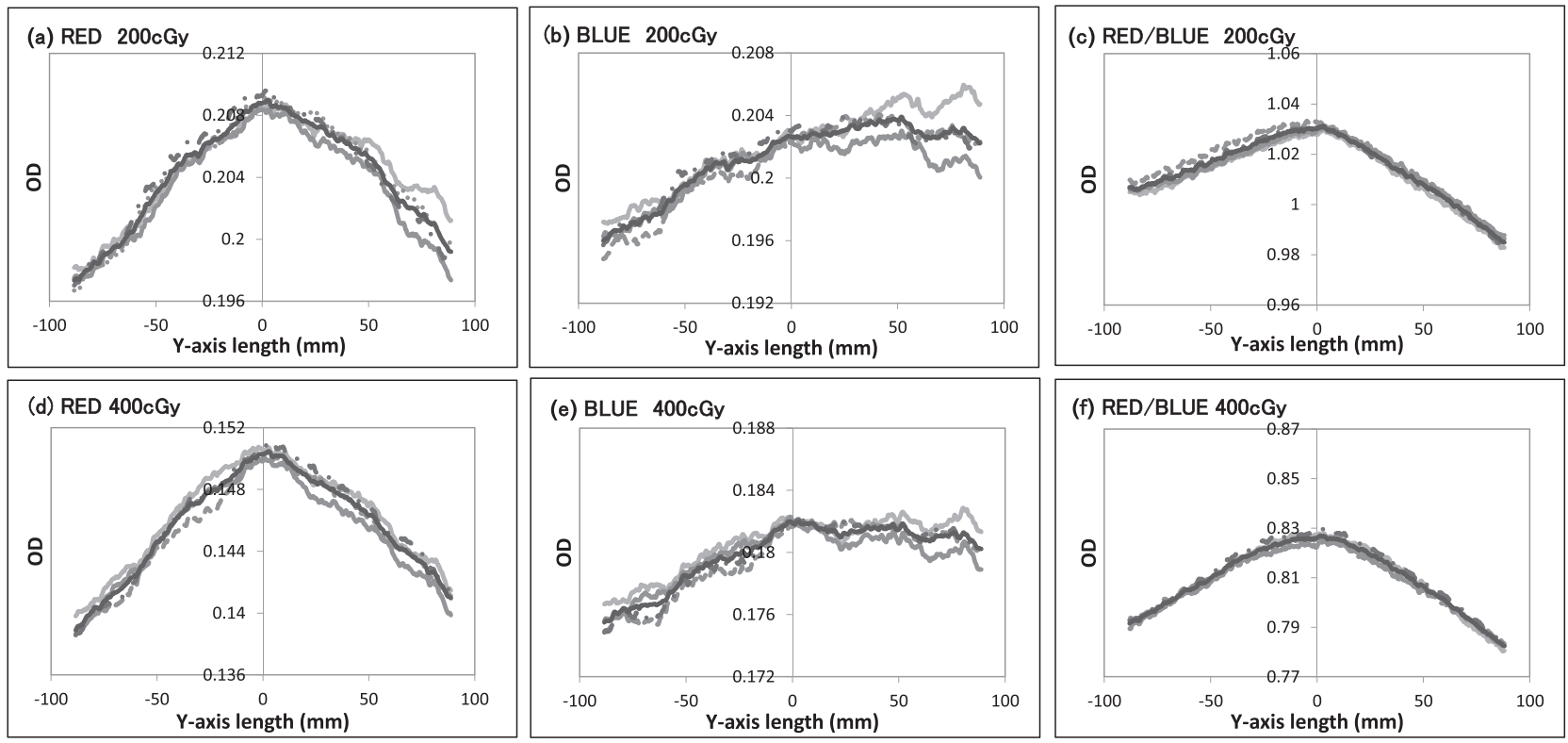

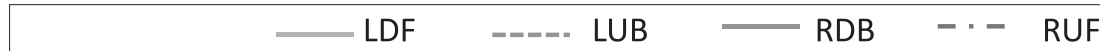

Average

Fig. 4 Optical density profile along the y-axis of EBT3 films irradiated with prescription dose of 200 cGy for (a) red, (b) blue and (c) $\mathrm{red} / \mathrm{blue}$,with prescription dose of $400 \mathrm{cGy}$ for (d) red, (e) blue and (f) red/blue components on different scanned directions. LDF: Left-Down-Front, LUB: Left-Up-Back, RDB: Right-Down-Back, RUF: Right-Up-Front
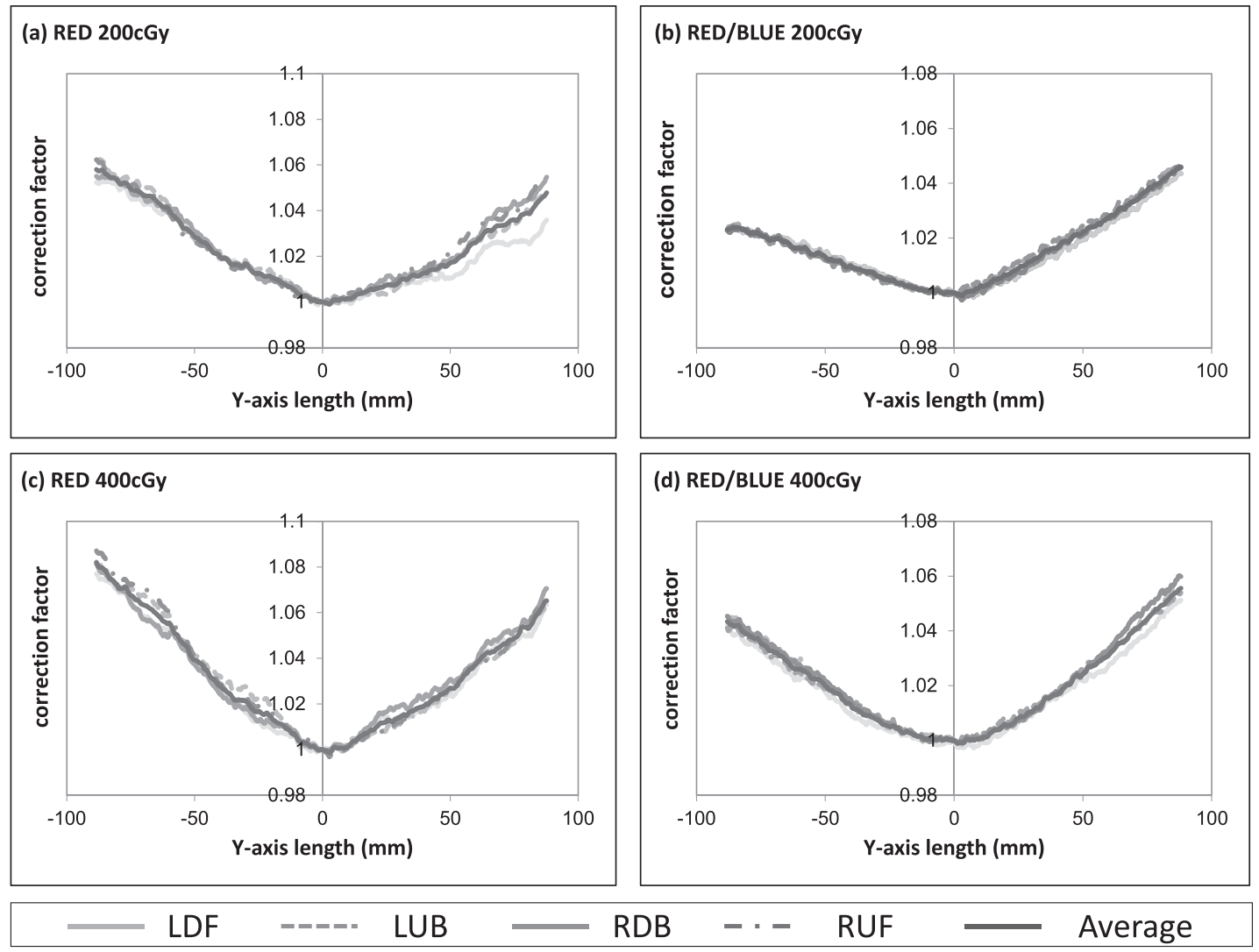

Fig. 5 Correction factor curves of optical density for (a) red and (b) red/blue components with the prescription dose of $200 \mathrm{cGy}$, and for (c) red and (d) red/blue components with the prescription dose of $400 \mathrm{cGy}$. LDF: Left-Down-Front, LUB: Left-Up-Back, RDB: Right-Down-Back, RUF: Right-Up-Front 


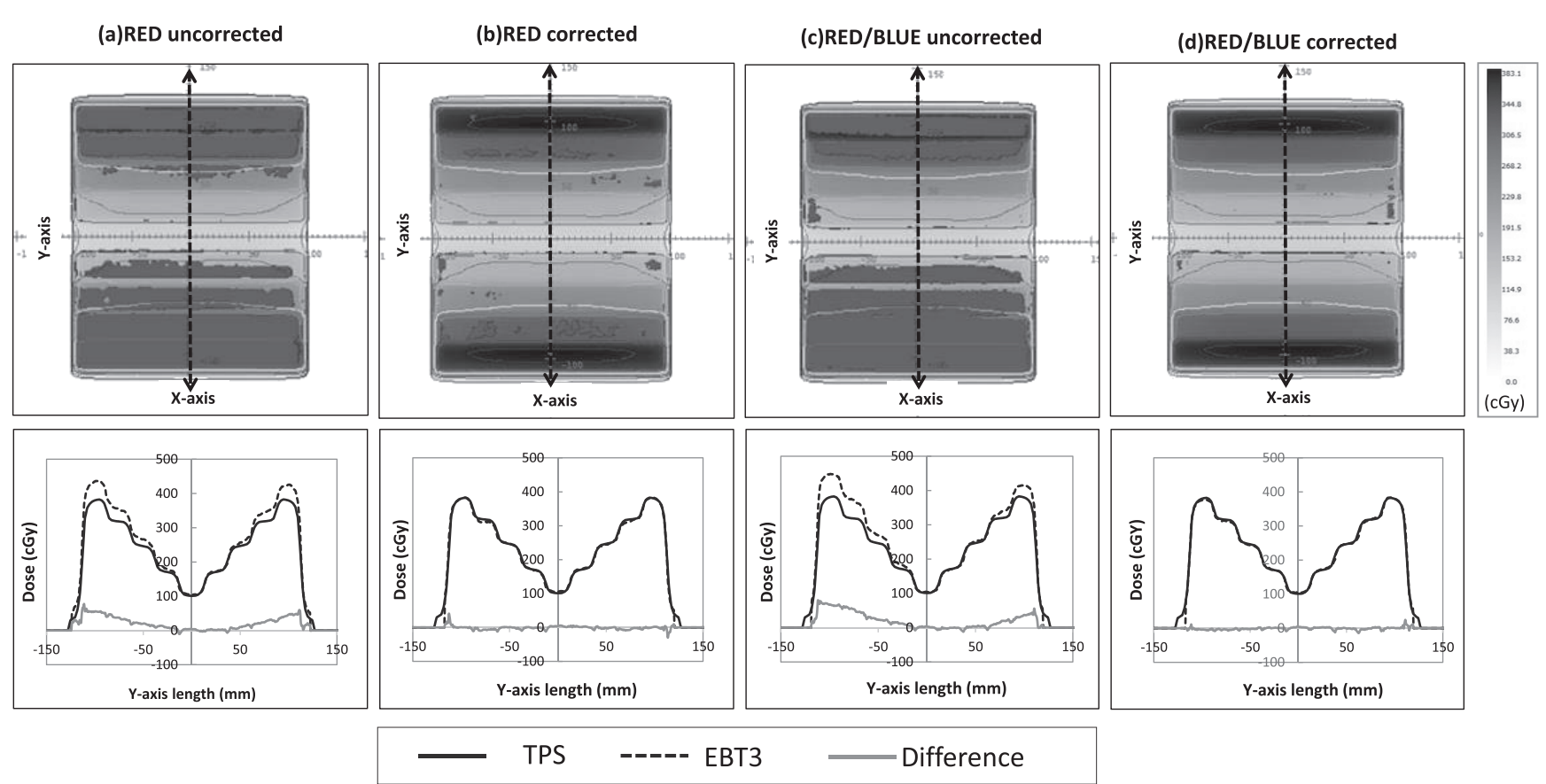

Fig. 6 Planar dose distributions and y-axis dose profiles of step pattern for (a) the uncorrected film of the red, (b) the corrected film of the red, (c) the uncorrected film of the red/blue and (d) the corrected film of the red / blue components, respectively.

Dash line with arrow indicates position of profile line. In the upper planar dose distributions, the $y$-axis is the vertical axis and the $x$ axis is the horizontal axis. In the lower dose profile, the vertical axis represents the dose and the horizontal axis represents the y-axis position in the upper planar dose distributions.

Table 1 Dose difference between TPS and EBT3 in step pattern

\begin{tabular}{|c|c|c|c|c|c|c|c|c|}
\hline \multirow{3}{*}{ Setting } & \multicolumn{4}{|c|}{ Error at $0 \mathrm{~mm}(\%)$} & \multicolumn{4}{|c|}{ Error at $100 \mathrm{~mm}(\%)$} \\
\hline & \multicolumn{2}{|c|}{ RED } & \multicolumn{2}{|c|}{ RED/BLUE } & \multicolumn{2}{|c|}{ RED } & \multicolumn{2}{|c|}{ RED/BLUE } \\
\hline & $\begin{array}{c}\text { Un- } \\
\text { corrected }\end{array}$ & Corrected & $\begin{array}{c}\text { Un- } \\
\text { corrected }\end{array}$ & Corrected & $\begin{array}{c}\text { Un- } \\
\text { corrected }\end{array}$ & Corrected & $\begin{array}{c}\text { Un- } \\
\text { corrected }\end{array}$ & Corrected \\
\hline RUF & 3.1 & 4.1 & 3.2 & 4.3 & 14.5 & 0.2 & 17.6 & -1.2 \\
\hline RDB & 3.4 & 3.1 & 4.4 & 2.6 & 19.5 & 1.6 & 23.7 & 1.7 \\
\hline LDF & 2.2 & 4.5 & 2.2 & 2.9 & 17.0 & 3.2 & 16.5 & 1.6 \\
\hline LUB & 2.7 & 4.9 & 1.7 & 3.6 & 14.1 & 1.6 & 17.4 & 0.2 \\
\hline Average & 2.9 & 4.2 & 2.9 & 3.4 & 16.3 & 1.7 & 18.8 & 0.6 \\
\hline SD & 0.5 & 0.8 & 1.2 & 0.7 & 2.5 & 1.2 & 3.3 & 1.4 \\
\hline $\begin{array}{l}\text { Average } \\
\text { lateral effect } \\
\text { correction } \\
\text { factor }\end{array}$ & - & 3.3 & - & 3.6 & - & 0.4 & - & 1.3 \\
\hline
\end{tabular}

RUF: Right-Up-Front, RDB: Right-Down-Back, LDF: Left-Down-Front, LUB: Left-Up-Back

Table 2 Pass rate of the step pattern with or without correction

\begin{tabular}{|c|c|c|c|c|}
\hline \multirow{3}{*}{ Setting } & \multicolumn{4}{|c|}{ Pass rate $(\%)$} \\
\hline & \multicolumn{2}{|c|}{ RED } & \multicolumn{2}{|c|}{ RED/BLUE } \\
\hline & $\begin{array}{c}\text { Un- } \\
\text { corrected }\end{array}$ & Corrected & $\begin{array}{c}\text { Un- } \\
\text { corrected }\end{array}$ & Corrected \\
\hline RUF & 42.3 & 93.5 & 45.0 & 96.7 \\
\hline $\mathrm{RDB}$ & 26.9 & 87.3 & 37.6 & 90.1 \\
\hline LDF & 33.1 & 84.1 & 48.4 & 84.4 \\
\hline LUB & 45.1 & 96.7 & 47.8 & 96.3 \\
\hline $\begin{array}{l}\text { Average lateral effect } \\
\text { correction factor }\end{array}$ & - & 89.8 & - & 94.7 \\
\hline
\end{tabular}

RUF: Right-Up-Front, RDB: Right-Down-Back, LDF: Left-Down-Front, LUB: Left-Up-Back 
(a)RED uncorrected
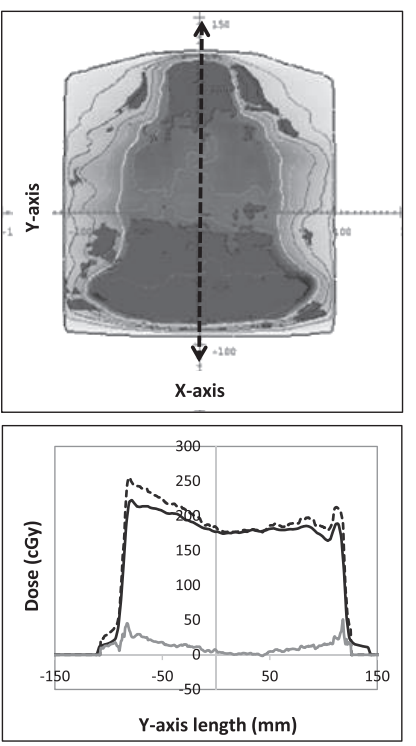

(b)RED corrected
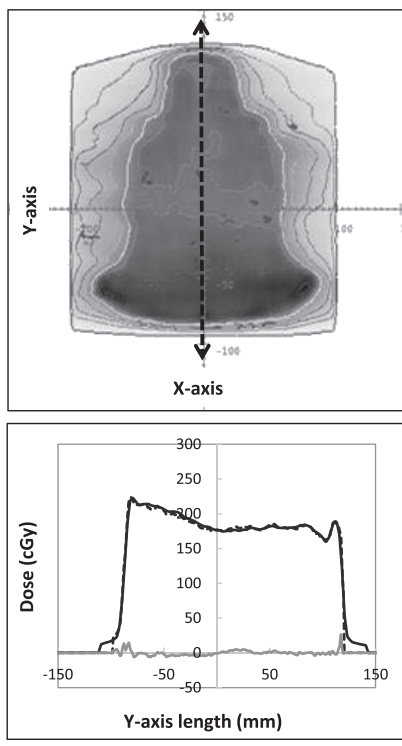

(c)RED/BLUE uncorrected
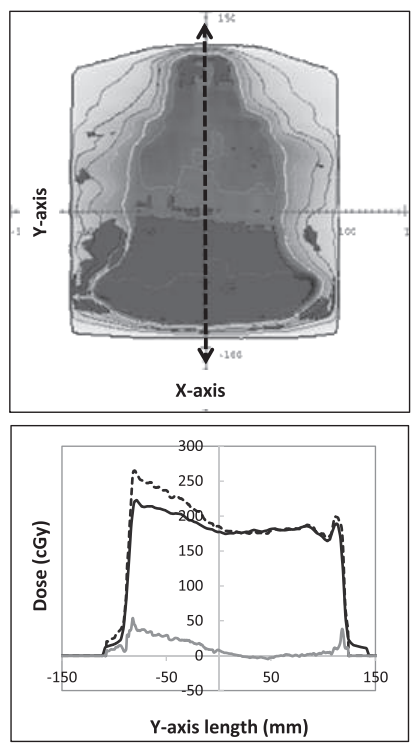

(d)RED/BLUE corrected

(cGy)

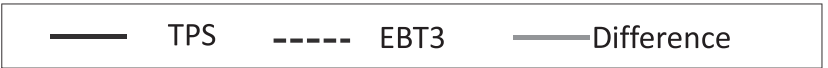

Fig. 7 Planar dose distribution and y-axis dose profile of IMRT plan for (a) the uncorrected film of the red, (b) the corrected film of the red, (c) the uncorrected film of the red/blue and (d) the corrected film of the red/blue components, respectively.

Dash line with arrow indicates position of profile line. In the upper planar dose distributions, the $y$-axis is the vertical axis and the $\mathrm{x}$ axis is the horizontal axis. In the lower dose profile, the vertical axis represents the dose and the horizontal axis represents the y-axis position in the upper planar dose distributions.

Table 3 Dose difference between TPS and EBT3 in IMRT plan

\begin{tabular}{|c|c|c|c|c|c|c|c|c|}
\hline \multirow{3}{*}{ Setting } & \multicolumn{4}{|c|}{ Error at $0 \mathrm{~mm}(\%)$} & \multicolumn{4}{|c|}{ Error at $80 \mathrm{~mm}(\%)$} \\
\hline & \multicolumn{2}{|c|}{ RED } & \multicolumn{2}{|c|}{ RED/BLUE } & \multicolumn{2}{|c|}{ RED } & \multicolumn{2}{|c|}{ RED/BLUE } \\
\hline & $\begin{array}{c}\text { Un- } \\
\text { corrected }\end{array}$ & Corrected & $\begin{array}{c}\text { Un- } \\
\text { corrected }\end{array}$ & Corrected & $\begin{array}{c}\text { Un- } \\
\text { corrected }\end{array}$ & Corrected & $\begin{array}{c}\text { Un- } \\
\text { corrected }\end{array}$ & Corrected \\
\hline RUF & 3.0 & -0.5 & 4.6 & 2.2 & 15.0 & 1.1 & 20.2 & 1.4 \\
\hline RDB & 3.7 & 2.2 & 5.1 & 3.6 & 15.8 & 2.4 & 21.9 & 3.2 \\
\hline LDF & 3.2 & 3.1 & 5.5 & 3.2 & 17.0 & 2.4 & 21.5 & 2.2 \\
\hline LUB & 3.0 & 1.2 & 5.3 & 2.6 & 17.0 & 1.5 & 21.1 & 1.7 \\
\hline Average & 3.2 & 1.5 & 5.1 & 2.9 & 16.2 & 1.8 & 21.2 & 2.1 \\
\hline $\mathrm{SD}$ & 0.3 & 1.6 & 0.4 & 0.6 & 1.0 & 0.6 & 0.7 & 0.8 \\
\hline $\begin{array}{l}\text { Average } \\
\text { lateral effect } \\
\text { correction } \\
\text { factor }\end{array}$ & - & 2.6 & - & 3.0 & - & 2.9 & - & 1.8 \\
\hline
\end{tabular}

RUF: Right-Up-Front, RDB: Right-Down-Back, LDF: Left-Down-Front, LUB: Left-Up-Back

Table 4 Pass rate of the IMRT plan with or without correction

\begin{tabular}{|c|c|c|c|c|}
\hline \multirow{3}{*}{ Setting } & \multicolumn{4}{|c|}{ Pass rate $(\%)$} \\
\hline & \multicolumn{2}{|c|}{ RED } & \multicolumn{2}{|c|}{ RED/BLUE } \\
\hline & $\begin{array}{c}\text { Un- } \\
\text { corrected }\end{array}$ & Corrected & $\begin{array}{c}\text { Un- } \\
\text { corrected }\end{array}$ & Corrected \\
\hline RUF & 60.6 & 98.7 & 63.3 & 98.6 \\
\hline RDB & 58.9 & 98.4 & 62.0 & 94.2 \\
\hline LDF & 61.2 & 91.1 & 59.5 & 90.8 \\
\hline LUB & 60.9 & 98.1 & 59.3 & 98.5 \\
\hline $\begin{array}{l}\text { Average lateral effect } \\
\text { correction factor }\end{array}$ & - & 96.1 & - & 98.5 \\
\hline
\end{tabular}

RUF: Right-Up-Front, RDB: Right-Down-Back, LDF: Left-Down-Front, LUB: Left-Up-Back 
かった，EBT3では，青色成分に比べて赤色成分は, 1000 cGy までの線量域で感度が高く lateral effect の 影響を強く受けたと考える ${ }^{12)}$. 青色成分は線量の感度 が低くフィルム固有のムラなどの情報を有しており，

Hayashi らや Palmer らが報告した補正方法である triple-channel 法に利用されている ${ }^{8,9)}$. スキャン方向 の違いによる OD は，青色成分における OD のバラッ キに示されるように EBT3 の感光物質形状が不規則 に存在しているため, スキャン方向によって不規則に 光を散乱させたと想定される。

本研究では, 赤色成分, 赤色/青色成分に扔けるス キャン方向を考慮した補正法を検討した，感光物質の 粒子による光拡散の違いを考慮して $1 \times 18 \mathrm{~cm}^{2}$ の面積 を 4 方向からスキャンして lateral effect 補正係数を 取得した。スキャン方向の違いによる lateral effect 補正係数は，最大で $1.0 \%$ 差が生じた。 $\mathrm{EBT} 3$ の OD は，スキャン方向によって 0.7-4.5\%変化することが報 告されている ${ }^{12)}$. $\mathrm{y}$ 軸位置の OD を利用する補正係数 は，EBT3のスキャン方向に影響を受けると考える．

ステップパターンの補正前後の線量プロファイル は, lateral effect 補正によって周辺部における線量差 は低減した，ガンマ解析では補正前後でガンマ值が 1 を超える領域は減少し, パス率は改善した. Lateral effect は高線量かつ周辺部で影響が大きく, 周辺部に 高い処方線量を設定したステップパターンにおいてパ ス率が改善したことは, 周辺部に高線量領域があった 場合でもスキャン位置に対して線量に応じた lateral effect 補正は正確に実施できたと考える。赤色/青色 成分は，赤色成分から青色成分が有するフィルム固有 のムラを除去しているため検証精度は高く, 本研究に おいてもパス率は赤色成分に比較して高かった，赤 色/青色成分のように複数のチャンネルを複合して用 いる方法は, フィルム保護層の厚みなどフィルム固有 の特性とフラットベッドスキャナの性質やスキャン条 件による不均一性を低減させるため, 過去の報告と同 様の結果であった ${ }^{5)}$. 本研究に扔いて, ステップパ ターンおよび頭頸部 IMRT プランのガンマ解析のパ 又率は, lateral effect 補正によって向上しており正確 度は高いと考える。 Lateral effect 補正は, 小照射野の 定位放射線治療ではなく大照射野の頭頸部領域や骨盤 部領域で有用であり, 本研究の手法は効果的な lateral effect 補正を行うことできると考える.

Lateral effect 補正法は, フラットベッドスキャナに 起因する誤差とフィルム固有のムラに起因する䛊差を 事前に調査して補正関数を作成する background correction 法がある10). Background correction 法は, 未
照射のフィルムを用いて照射後のフィルムからフィル ム固有のムラの情報を除去し補正することで lateral effectを $8 \%$ から 2.5\%に低減できると報告されてい る。本研究では, $\mathrm{y}$ 軸周辺部の線量差の平均值は, ス テップパターンにおいて赤色成分で $14.6 \%$, 赤色/青 色成分で $18.2 \%$, 頭頸部 IMRT プランにおいて赤色成 分で $14.4 \%$ ，赤色/青色成分で 19.1\%低減できた。本 研究における lateral effect 補正は, background correction 法と比べて y 軸位置に対する線量を考慮して いるため標的臓器やリスク臟器の位置における線量分 布検証を正確に評価し, 更に RCF の不確かさの一つ であるフィルム固有のムラの影響を低減できると考え られる ${ }^{13,14)}$. Average lateral effect 補正係数は, 照射 野が大きくスキャン方向が特性曲線取得時と一致させ ることができない場合に，再度特性曲線を取得しなく ても赤色成分においてステップパターンで $5.7 \%$, 頭 頸部 IMRT プランで $5.0 \%$, 赤色/青色成分においてス テップパターンで $10.3 \%$, 頭頸部 IMRT プランで $7.7 \%$ と補正精度を改善できるため有用と考える.

本検討は, ステップパターンと頭頸部 IMRT プラ ンに対してファントムを使用して, フィルム線量分布 を評価した。臨床デー夕を使用した lateral effect 補 正の有用性を検討することは重要であり，今後更なる 検討が必要である.

\section{4. 結 語}

本研究では, 線量分布検証のために使用する EBT3 においてフラットベッドスキャナによるスキャン時に 発生するスキャナ由来の不均一性を補正する方法を検 討した. Lateral effect 補正は, 走査垂直方向の周辺部 で影響が大きいため大照射野で必要性が高く, 補正す ることで線量プロファイルとパス率は TPS で計算さ れた線量分布と良好な一致を示した。本研究で提案し た average lateral effect 補正係数は, 特性曲線取得時 と線量分布検証時のフィルムスキャン方向を一致さ せることができない比較的広範囲な治療領域で有用で ある。

\section{謝 辞}

本研究に際しご指導いただいた県立広島病院放射線 治療科主任部長の和田崎晃一氏に感謝申し上げます。

なお, 本研究の要旨はガフクロミックフィルム研究 会 (2017 年, 大阪)にて発表した. 


\section{利益相反}

共著者の宮沢正則は，アールテック有限会社の社員

である。それ以外の共著者に，開示すべき利益相反は

ない.

\section{参考文献}

1) IMRT 物理 QA ガイドライン専門小委員会 (日本放射線腫 瘍学会 QA 委員会)。強度変調放射線治療における物理・ 技術的ガイドライン 2011. https://www.jastro.or.jp/customer/guideline/2016/10/IMRT2011.pdf(アクセス日: 2019 年 1 月 20 日).

2) Miura H, Ozawa S, Hosono F, et al. Gafchromic EBT-XD film: dosimetry characterization in high-dose, volumetric-modulated arc therapy. J Appl Clin Med Phys 2016; 17(6): 312-322.

3) Menegotti L, Delana A, Martignano A. Radiochromic film dosimetry with flatbed scanners: a fast and accurate method for dose calibration and uniformity correction with single film exposure. Med Phys 2008; 35(7): 3078-3085.

4) Poppinga D, Schoenfeld AA, Doerner KJ, et al. A new correction method serving to eliminate the parabola effect of flatbed scanners used in radiochromic film dosimetry. Med Phys 2014; 41(2): 021707.

5) Micke A, Lewis DF, Yu X. Multichannel film dosimetry with nonuniformity correction. Med Phys 2011; 38(5): 2523-2534.

6) Kairn T, Aland T, Kenny J. Local heterogeneities in early batches of EBT2 film: a suggested solution. Phys Med Biol 2010; 55(15): L37-42.

7) Aland T, Kairn T, Kenny J. Evaluation of a Gafchromic EBT2 film dosimetry system for radiotherapy quality assurance. Australas Phys Eng Sci Med 2011; 34(2): 251-260.

8) Hayashi N, Watanabe Y, Malmin R, et al. Evaluation of triple channel correction acquisition method for radiochromic film dosimetry. J Radiat Res 2012; 53(6): 930-935.

9) Palmer AL, Dimitriadis A, Nisbet A, et al. Evaluation of Gafchromic EBT-XD film, with comparison to EBT3 film, and application in high dose radiotherapy verification. Phys Med Biol 2015; 60(22): 8741-8752.

10) Saur S, Frengen J. GafChromic EBT film dosimetry with flatbed CCD scanner: a novel background correction method and full dose uncertainty analysis. Med Phys 2008; 35(7): 30943101.

11）上原隆三, 橘 英伸, 伊藤 康, 他. 線量分布解析におけ るラジオクロミックフィルムドジメトリーの正確性の向 上に関する取り組み一フラットベッドスキャナの影響の 補正法と色成分を利用した補正法の組み合わせ一. 日放 技学誌 2013; 69(6): 617-631.

12) Casanova Borca V, Pasquino M, Russo G, et al. Dosimetric characterization and use of GAFCHROMIC EBT3 film for IMRT dose verification. J Appl Clin Med Phys 2013; 14(2): 4111.

13) Andrés $C$, del Castillo A, Tortosa $R$, et al. A comprehensive study of the Gafchromic EBT2 radiochromic film. A comparison with EBT. Med Phys 2010; 37(12): 6271-6278.

14) Bouchard H, Lacroix F, Beaudoin G, et al. On the characterization and uncertainty analysis of radiochromic film dosimetry. Med Phys 2009; 36(6): 1931-1946. 